\title{
STUDY OF LARYNGEAL TRAUMA DUE TO ENDOTRACHEAL INTUBATION IN AUTOPSIED CASES
}

\author{
HIRO-OMI TAKAHASHI, M.D., KINYA TAKEMOTO, M.D., \\ MASAMICHI SHIROTA, M.D., TOURU SUZUKI, M.D., \\ ROKURO KAWANO, M.D., MAKOTO ODA, M.D., \\ NAOKI TASHIRO, M.D. AND TETSUYA SHITARA, M.D. \\ Department of Otolaryngology, School of Medicine, Kitasato University \\ (Director: T. Shitara, M.D.)
}

\begin{abstract}
In order to study the pathological findings of the larynx due to the endotracheal intubation, the frontal sections of the larynx from thirty-two autopsied cases, 23 of intubated and 9 of non-intubated cases, were examined microscopically with $\mathrm{HE}$ staining.

The exfoliation (ulcer) or the separation of the epithelium and the samall round cell infltration in the subepithelial layer were found in both intubated and non-intubated cases. The edema and the capillary dilatation in the submucosal layer were noted more in the intubated group than the non-intubated one. The submucosal hemorrhage was found in seven out of 23 intubated cases. The neutrophile leucocyte infiltration under the epithelium of the larynx was observed in six tutubated cases who had been intubated over ten hours. It is possible that the intubation over ten hours may induce laryngeal complications.
\end{abstract}

A $81-0315-61711$

\section{気管内㨀管による声带の病変}

一一剖 検 例 $の$ 検 討一

北旦大学医学部耳竟咽喉科学教室 (主任: 設楽赽也教授)

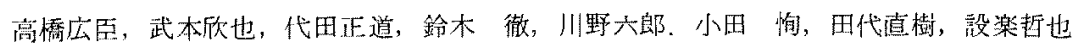

\section{I。はしめに}

近年, 麻酥学の著しい進歩によって全身麻酸が安全加 つ頻回に行われるようになったために気管内挿管の技術 が広く行きかたった，重篤また緊急の呼吸障害に対し て，気管切開術飞代って気管内掅管による呼吸管理が行 われることが多くなったが同時汇特有な合㐼怔の報告屯 みられている，最近は插管用チューブの材質や消毒法に

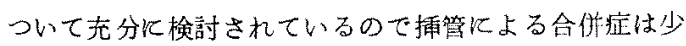
なく安全性は極めて高いとい光る、しかし合㐼症が皆䑲 となったわけではなく，また全身状態の悪い患者に緊急 処置として插管した場合なとは，時に不適当なチューブ が拆入されることもあって，喉頭や気管に障害を选こし 二次的処置吕必要机る.

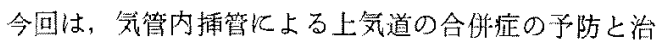
療を目標として，気管内㧴管によって声带に生じた病变 を剖検例について観祭したので報告する。

対 象

病院病理部で病理解剖を行った症例のうち血液疾忠， 耳鼻咽喉科疾患などを除いた32例方対象とした。

死因となった主大る疾病は，墨性腫痛 18，媨血管障害

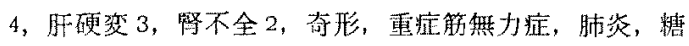
尿病，頭部外偒が各 1 でった。

年龄分布は，10 20 歳代 2, 30 歳代 3，40 歳代 6 (女

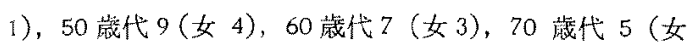

1)て，最年少者10歳男，最年長者78筬男であった。 部検例中，呼吸不全のため緊重に気管内挿管を行って 
呼吸を管理したにもかかわらず死亡した症例が 23 例あ り, 㨂管時間は12分から最長 7 日にわっていた. チュー ブの太さは Fr. No. 32 程度のものが多いが記载されて いない症例も多く不明である、チューブの材質はラテッ クス, プラスチック (PVC), 赤ゴム等で隇菌法はエチ レンオキサイドガス $7 \sim 8$ 時間隇菌によるものが大部分 であるが，緊急毦管されている症例が多いので正確で は放い，去た気管内插管を行った医師は麻酔專門医とは 限らない。 カフ使用の有無とついても記載がないものが 多い.

非㨂管例が 9 例あり, 対照とした。

\section{研 究方法}

挿管23例, 非挿管 9 例の喉頭について, 声帯の中 $1 / 3$ 部位（なるべく後方）の前額断面の病理組織標本を作製 し, HE 染色にて検鏡した.

声帯の病変として粘膜上皮欠損（上皮下組織の欠損を 含む）（図 1）, 上皮遊離（図 2）, 粘膜下浮腫または毛 細血管拡張 (図 3), 粘膜下出血 (図 2), 好中球浸潤 (図 4), 小円形細胞浸潤の 6 項目につき検討した.

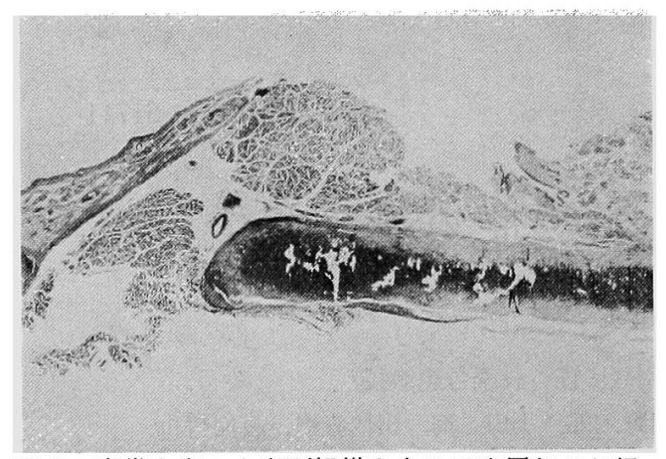

図 1 声带上皮, 上皮下組織を含めて表層部の欠損 がある. $\mathrm{HE} \times 2$

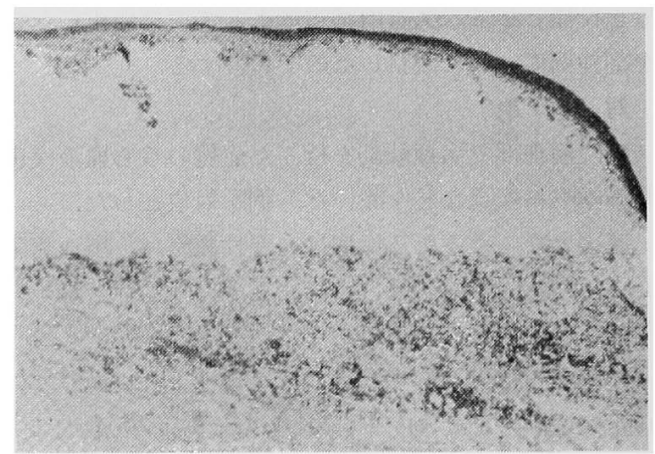

図 2 上皮下に出血している部で上皮が剥離. HE $5 \times 4$

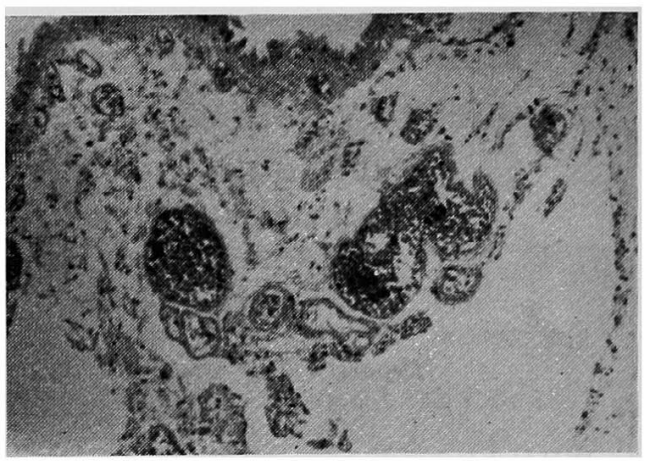

図 3 粘膜下に毛細血管拡張及び浮腫を認める. $\mathrm{HE} 5 \times 10$

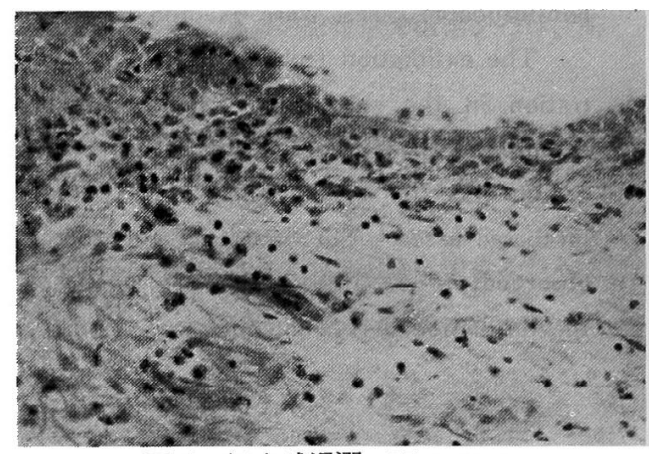

図 4 好中球浸潤 HE $5 \times 20$

結果

粘膜上皮（上皮下組織を含む）の欠損, 遊離, 小円形 細胞浸潤は表 1 亿示す如く插管群と対照との間に差はみ られなかった. 殊飞小円形細胞浸潤は插管, 非插管にか かわらず大部分の症例 (插管例 21/23, 非插管例 6/9) に認められた。

粘膜下の浮腫または毛細血管拡張はやや插管例に多い 傾向がみられた（表 1). また粘膜下に出血が認められた

表 1 声帯の病理組織所見（）内 女性

\begin{tabular}{|c|c|c|}
\hline & $\begin{array}{c}\text { 㨉管 例 } \\
23(8)\end{array}$ & $\begin{array}{c}\text { 非插管例 } \\
9(1)\end{array}$ \\
\hline 上 皮 欠 損* & $8(6)$ & $3(1)$ \\
\hline 皮遊 & $8(3)$ & $4(0)$ \\
\hline 粘 膜 下 出 血 & $7(3)$ & \\
\hline 浮腫または毛細血管拡張 & $15(6)$ & $2(0)$ \\
\hline 好 中 球 浸 潤 & $6(4)$ & \\
\hline 小円形細胞 浸潤 & $21(8)$ & $6(0)$ \\
\hline
\end{tabular}

* 上皮下組織を含めた声帯の表層欠損が含まれている. 
表 2 組織所見の維み合わ甘

\begin{tabular}{|c|c|c|c|c|c|c|}
\hline & $\begin{array}{l}\text { 上 } \\
\text { 皮 } \\
\text { 尔 } \\
\text { 損 }\end{array}$ & $\begin{array}{l}\text { 上 } \\
\text { 皮 } \\
\text { 遊 } \\
\text { 碓 }\end{array}$ & 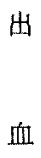 & 浮 & $\begin{array}{l}\text { 好 } \\
\text { 中 } \\
\text { 球 }\end{array}$ & $\begin{array}{l}\text { 小 } \\
\text { 円 } \\
\text { 形 } \\
\text { 絗 } \\
\text { 鵤 }\end{array}$ \\
\hline 上皮欠損 8 & & 2 & 3 & 6 & 3 & 7 \\
\hline 上皮游離 8 & 2 & & 3 & 4 & & 8 \\
\hline 出 血 7 & 3 & 3 & & 7 & 3 & 6 \\
\hline 浮腫 15 & 6 & 4 & 7 & & $\mathbf{5}$ & 13 \\
\hline 好中球 6 & 3 & & 3 & 5 & & 6 \\
\hline 小円形細胞21 & 7 & 8 & 6 & 13 & 6 & \\
\hline
\end{tabular}

仹|

好中球漫潤あり

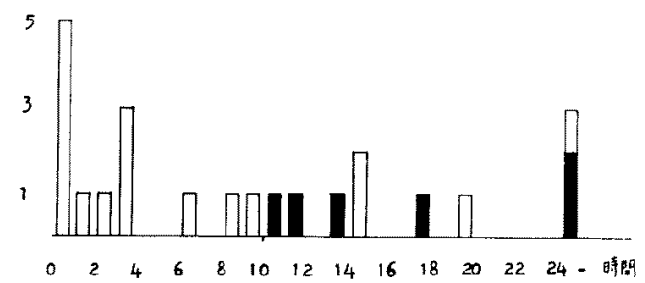

図 5 插管時䦎之好中球浸潤，10時閒以上の挿管例 に好中球の浸潤がみられる。

症例は全例浮腫がみられ，炶膜下に好中球の浸閏をみ た症例は同時に粘膜下浮腫や出血をるることが多かった (表 2).

粘膜下出血と好中球浸膶は，小ずれも插管例にのみみ られた变化で殊飞好中球の浸潤は图5にみられるように

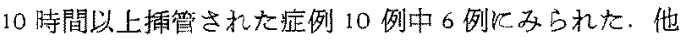
の病変飞ついて时間との相関はるられなかった。

男女差については対照例飞女性が少なく何ともいえな い.

年龄による差はみられなかった。

\section{総括打よび考按}

初めに述べた如くかって気管切開の噵応であった症例 に気管内㨉管による救命処置がとられることが多くなっ

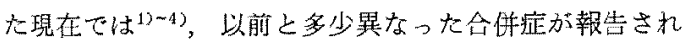

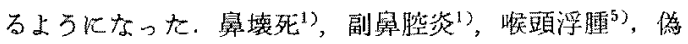

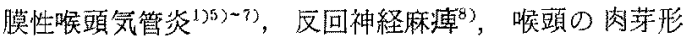

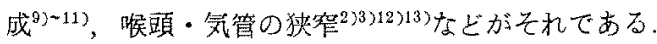

今回著者らは気管内插管による上気道の重籊な合併症 が，少ない類度ながら経験されることから上気道にどの ような病变が生しているかを知るためにまず声带の病变
を観繁する作業をはじわた，ただし対象は脳外傷の1例 を除いて消耗性疾患患者の病期末に生じた呼吸障害に詨 する緊急炕置として插管されたこと，插管した医師は必 すしも麻䁣門医ではないこと，剖検例のため死後変化 を考虑しなければならないこと，また剖検時に声帯の後 $1 / 3$ が損㑭されているため代りに中1/3の部位の変化を みていることなどの制約がある。

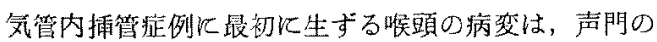

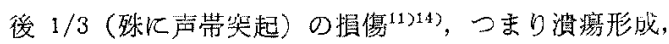
出血等とそれに続く浮腫，細胞浸㵎などである。自験例

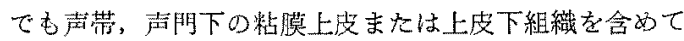
欠搷している症例が23例中 8 例 (34.8\%) 飞みられたが。 非播管例儿も 9 例中 3 例 $(33.3 \%)$ に同様な所見がみら れ剖検例では死後变化が含まれている可能性を考慮しな けれはならない、しかし動物実鈋等であきらかにチュー ブの聥入によって上皮が知損することが確認されてい $ろ^{(1)(4) \sim 16)}$

上皮の遊陮についても自駼例では上皮久鲃の場合と同 じ傾向をみた。また粘膜下出血がある場所で上皮が上 皮下組織から進離している所見が眭にみられた。

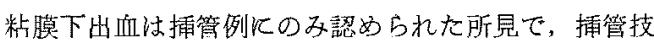
術，插管後の体動，咳制発作などと関係があるだるう。 前述したように出血部位で上皮が遊晟している所睍があ り，粘膜面の潰瘍形成加ら肉芽增生八と進行する可能性

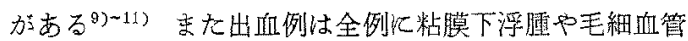
の拡張がみられたことから㗇頭浮蕾の原因の一つとして 出血が考えられた。

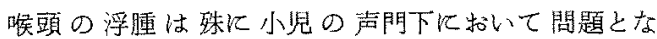
る ${ }^{12}$. 目娩例では描管例にやや多くみられたがいずれも

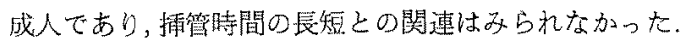

粘膜下の好中球漫潤は括管例飞のみみられた病変で， いずれも10時間以上插管された症例であった。また同時 に浮腄や出血を伴ろことが多加った. Burton ${ }^{11)}$ によれぱ 成人では48時間が比較的安全な電管時間の限界で72時間 以上は障嗐老机こす危険があるとし，Harrison" の諭文 には8 時間が 1 週間にわたる各研究者の詵が列举され ている、篟なる気道確保を目的とした場合と麻酥の插等 とは異なるし ${ }^{15}$ ，症例の全身状態とも関係が深いと予想 されるが，著者らは10时閴以上の㨉管は留染の危険が堌

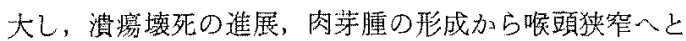
移行する頻度が高くなると考えた。

数膜下の小円形細胞浸潤は，插管，非擂管のいずれの 群にも高率にみられ，慢性喉頭炎を有する症例が多いこ 
とを示している.

おわりに

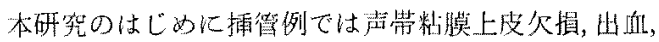
浮腫，緗胞浸澗惢どの变化が多いと子想したが，奏際に は粘膜下出血，好中球浸膶のみが插門例にみられた病变

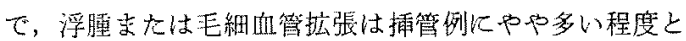
いう結榦よなった。また粘膜下に出血を生ずるような操

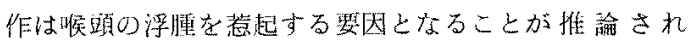

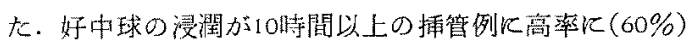
認められたことから，10時間以上の插管は肉芽形成扣上 び喉頭狭窄の原因上な万可能性吕离い上考えられた。

\section{文萳}

1) Harrison, G. A. et al.: Prolonged (therapeutic) endotracheal intubation. Brit. J. Anaesth., 40; $241-249,1968$.

2) Abbott, T. R. Complications of prolonged nasotracheal intubation in children. Brit. J. Anaesth., 40; 347-353, 1968.

3) Aass, A.S.: Complications to tracheostomy and long-term intubation: A follow-up study. Acta Anaesth. Scand., 19; 127-133, 1975.

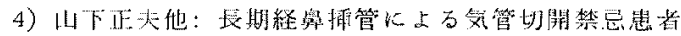

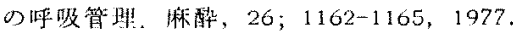

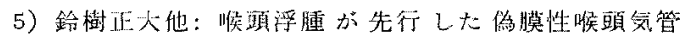
炎。麻醉，23；1124-1129，1974.

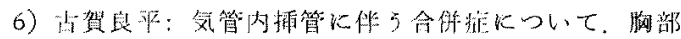
外科, 7; 991-994, 1954.

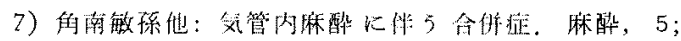
$269-270,1956$.

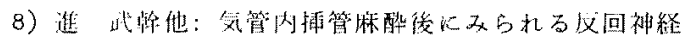

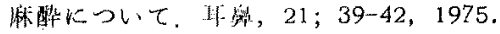

9) Smith, R. O. et al:: Post-intubation subglottic granulation tissue: Review of the problem and evaluation of radiotherapy. Laryngoscope, 79; $1227-1251,1969$.

10) Verhoog-Bloembergen, $M . P . J$, et al.: Longterm nasotracheal intubation. Int. Anesth. Clin.., $12 ; 241-257,1974$.

11) Burton, F. J.: Postoperative hoarseness. Amer. J. Surg., 123; 432-437. 1972.

12) Fearon, B. et al.: Airway problems in children following prolonged endotracheal intubation. Ann. Otolaryngol., 75; 975-986, 1966.

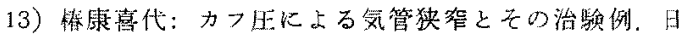
䍊食会報, $28 ; 10-17,1977$.

14) Hilding, A.C.: Laryngotracheal damage during intratracheal anesthesia. Ann. Otolaryngol, 80; $565-581,1971$.

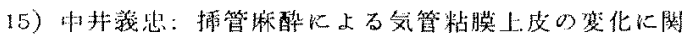

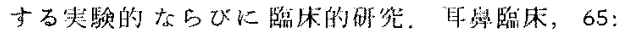
$311-326,1972$.

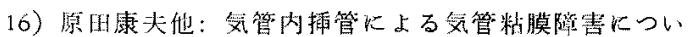

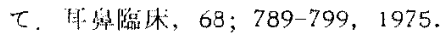

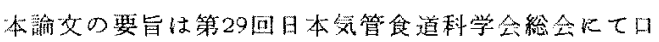
嘟L.

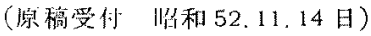

别刷請水先

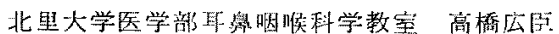

